\title{
3.22 EARLY FOOD PRODUCTION IN SOUTHWESTERN EUROPE
}

\author{
JOÃO ZILHÃO
}

In Chapters 3.21 and 3.22, we discuss the origins of food production in southern Europe. We divide our discussion into a southeastern part (Greece, Bulgaria, FYROM, Albania, Serbia and Montenegro, Bosnia and Herzegovina, Croatia, Slovenia, Hungary, Romania, Moldova, Ukraine and part of Russia), covered in Chapter 3.2I; and a southwest part (Italy, southern France, the Iberian Peninsula and the Western Mediterranean islands), discussed in this chapter. We take the narrative of agricultural origins from the 8th to the mid-6th millennium BCE. This narrative continues in Chapter 3.23, where Peter Bogucki deals with the early farmers of northern Europe.

\section{Issues of Tempo and Mode}

The identification of the wild variety in modern cultivated fields of wheat from the southern Balkans (Harlan 1976) underpinned postwar speculations that the original geographical distribution of the main domesticates extended into Europe and, therefore, contra Childean ex oriente lux views of the origins of food production, that the neolithisation of the continent could have been a largely independent process (Higgs \& Jarman I969; Dennell I983). In the Western Mediterranean, where wild cereals remained (and remain) unknown, such speculations rested upon the notion that the ancestors of sheep, goats, cattle and pigs were, respectively, the Corsican mouflon, the ibex and the indigenous populations of aurochs and wild boar. Although full consensus has yet to be reached (see the previous chapter on Southeast Europe), the combined evidence from archaeology, genetics and palaeogenetics (Zeder 2008, 2009) has now largely settled these origins issues by showing that (a) wheat and barley were domesticated in the Near East, to where, I2,500 to Io,000 years ago, their wild ancestors were restricted and where their domestication was the outcome of a millennialong process beginning with intensive cultivation and ending in the emergence of significant morphological change; (b) the Corsican mouflon derives from domestic sheep gone feral, not from a European population of the wild ancestor, Ovis orientalis, whose natural distribution is restricted to the Near East; (c) likewise, the wild ancestor of goats is the Near Eastern species, Capra aegagrus, not either of the European species, Capra ibex and Capra pyrenaica; (d) European cattle descend from Near Eastern populations that, after introduction, underwent geographically variable hybridisation processes with local aurochsen; and (e) the earliest Neolithic pigs were also of Near Eastern origin, with local domestication events, from which modern European pigs mostly derive, occurring only at a later time (the earliest "genetically European" domestic pigs were identified at the site of Bercy, in France, which dates to the early $4^{\text {th }}$ millennium cal $\mathrm{BCE}$, almost two millennia after food production economies are first recorded in the region; Larson et al. 2007).

These developments carry the necessary implication that models of an indigenous development of food production economies in the Western Mediterranean (Olària I988; Ramos et al. 2003) can now be confidently rejected. The same applies, however, to the polar alternative to such models - based on Ammerman and Cavalli-Sforza's (I973, I984) demic diffusion by "wave of advance". In fact, the development and growing application of AMS radiocarbon dating, beginning in the mid-rg8os, made it possible to measure the age of individual cereal seeds or of small samples of bones and teeth from domesticated animals, their human owners and artifacts made thereof. With this technique, one could finally overcome the problem of association between dated samples (e.g., charcoal from archaeological deposits) and the events the samples are intended to date (the human activities recorded by the artifacts and features found in the same levels). This problem is critical for the study of the origins of food production in the Western Mediterranean because most of the evidence comes from cave and rock shelter sites with continuous sedimentary sequences spanning the Mesolithic-Neolithic transition, where postdepositional disturbance (e.g., animal burrowing) and palimpsest formation (due to compression into a single recognisable "level" of what in fact is a succession of different occupational events) are ubiquitous. Moreover, with the AMS technique one could also bypass the so-called old wood effect; by dating short-lived samples (seeds, fruits, bone) instead of bulk charcoal samples, the danger was avoided of obtaining ages that reflected the time of growth of the inner trunk of trees that could already be many centuries-old when felled for fuel or timber. 
TABLE 3.22.I. Earliest Neolithic sites of the Western Mediterranean, per region (dated on direct indicators of food production or on unambiguously associated short-lived samples). For locations, see Map 3.22.I. Calibration (Reimer et al. 2009) used Calib 6.ohtml (http://calib.qub.ac.uk/calib/calib.html) with the INTCALog curve, except for the Cabranosa sample, which was calibrated with MARINEog.

\begin{tabular}{|c|c|c|c|c|c|c|c|}
\hline Site Name & Ware Type & Sample & Lab Number & Date вр & $\begin{array}{l}\text { Cal все (2 } \\
\text { Interval) }\end{array}$ & $\begin{array}{l}\text { Cal вСЕ } \\
\text { (Mid-point of } \\
\text { the Interval) }\end{array}$ & Reference \\
\hline Coppa Nevigata & $\begin{array}{l}\text { Southern Italian } \\
\text { Impressa }\end{array}$ & $\begin{array}{l}\text { Barley seeds } \\
\text { Barley seeds }\end{array}$ & $\begin{array}{l}\text { OxA-I474 } \\
\text { OxA-I475 }\end{array}$ & $\begin{array}{l}6850 \pm 80 \\
6880 \pm 90\end{array}$ & $\begin{array}{l}5967-5621 \\
5978-5630\end{array}$ & $\begin{array}{l}5794 \\
5804\end{array}$ & $\begin{array}{l}\text { Hedges et al. } \\
\text { r989 }\end{array}$ \\
\hline La Marmotta & $\begin{array}{l}\text { Southern Italian } \\
\text { Impressa }\end{array}$ & $\begin{array}{l}\text { Oak wood } \\
\quad \text { (radiocarbon }\end{array}$ & n plus tree-ring) & & $5502-5480$ & $549 \mathrm{I}$ & Kromer 2009 \\
\hline Arene Candide & Ligurian Impressa & Barley seeds & Beta-IIO542 & $6830 \pm 40$ & $5789-5638$ & 5714 & $\begin{array}{l}\text { Binder \& } \\
\quad \text { Maggi 200I }\end{array}$ \\
\hline Pendimoun & Cardial & $\begin{array}{l}\text { Acorns in } \\
\text { burial }\end{array}$ & Ly-5340 & $6490 \pm 75$ & $56 \mathrm{II}-53 \mathrm{I} 8$ & 5464 & Binder 1995 \\
\hline Can Sadurní & Cardial & $\begin{array}{c}\text { Cereal in } \\
\text { vessel }\end{array}$ & UBAR-760 & $6405 \pm 55$ & $548 \mathrm{I}-5299$ & 5390 & $\begin{array}{l}\text { Blasco et al. } \\
2005\end{array}$ \\
\hline Chaves & Cardial & Acorn in silo & GrA-2834I & $6380 \pm 40$ & $547 \mathrm{I}-5303$ & 5387 & $\begin{array}{c}\text { Zapata et al. } \\
2008\end{array}$ \\
\hline El Barranquet & Ligurian Impressa & Sheep bone & Beta-22I43I & $6510+50$ & $5606-5367$ & 5486 & $\begin{array}{l}\text { Bernabeu et al. } \\
2009\end{array}$ \\
\hline Mas d'Is & Ligurian Impressa & $\begin{array}{l}\text { Barley seed } \\
\text { Barley seed }\end{array}$ & $\begin{array}{l}\text { Beta-I66727 } \\
\text { Beta-I62092 }\end{array}$ & $\begin{array}{l}6600 \pm 50 \\
6600 \pm 50\end{array}$ & $\begin{array}{l}5620-548 \mathrm{I} \\
5620-548 \mathrm{I}\end{array}$ & $\begin{array}{l}555^{\circ} \\
555^{\circ}\end{array}$ & $\begin{array}{l}\text { Bernabeu et al. } \\
2009\end{array}$ \\
\hline Nerja & Ligurian Impressa & Sheep bone & Beta-I31577 & $6590 \pm 40$ & $5616-5480$ & 5548 & Aura et al. 2005 \\
\hline Cabranosa & Cardial & $\begin{array}{l}\text { Mussel shells } \\
\text { in hearth }\end{array}$ & Sac-I32I & $6930 \pm 60$ & $5603-5372$ & 5488 & $\begin{array}{l}\text { Cardoso et al. } \\
\text { I996 }\end{array}$ \\
\hline $\begin{array}{l}\text { Galeria da } \\
\text { Cisterna } \\
\text { (Almonda) }\end{array}$ & $\begin{array}{l}\text { Cardial (in } \\
\text { palimpsest with } \\
\text { Epicardial and } \\
\text { Ligurian Impressa } \\
\text { pottery) }\end{array}$ & $\begin{array}{l}\text { Pierced deer } \\
\text { canine } \\
\text { Bone bead }\end{array}$ & $\begin{array}{l}\text { OxA-9287 } \\
\text { OxA-9288 }\end{array}$ & $\begin{array}{l}6445 \pm 45 \\
6445 \pm 45\end{array}$ & $\begin{array}{l}5480-5328 \\
5480-5328\end{array}$ & $\begin{array}{l}5404 \\
5404\end{array}$ & Zilhão 2001 \\
\hline El Mirador & Uncertain & $\begin{array}{l}\text { Emmer wheat } \\
\text { seed }\end{array}$ & Beta-208I34 & $6300 \pm 50$ & $5463-5078$ & 5270 & $\begin{array}{l}\text { Vergès et al. } \\
2008\end{array}$ \\
\hline El Mirón & Undecorated & $\begin{array}{l}\text { Emmer wheat } \\
\text { seed }\end{array}$ & GX-30910 & $5550 \pm 40$ & $4457-433^{8}$ & 4398 & $\begin{array}{c}\text { Peña-Chocarro } \\
\text { et al. } 2005\end{array}$ \\
\hline
\end{tabular}

The impact of this progress in dating techniques is clearly apparent in two cases from Italy: at Coppa Nevigata (Foggia), a bulk charcoal result suggested an age of $\sim 6800 \mathrm{cal}$ BCE, but two AMS results on cereal seeds rejuvenated the site's Early Neolithic occupation by a millennium; and at San Marco (Perugia) three AMS cereal dates placed the occupation no earlier than $\sim 5400$ cal BCE, whereas a number of conventional results from other sites suggested that the Neolithic began in central Italy $\sim 6200 \mathrm{cal}$ BCE, if not even earlier (Hedges et al. I989, I990; Zilhão 200I; Skeates 2003). These examples make it clear that understanding the chronology of the MesolithicNeolithic transition requires (a) removing from consideration all potentially suspect results and (b) retaining as valid only those on short-lived samples that are unambiguously associated with, or are themselves direct indicators of, the Neolithic. When these criteria of chronometric hygiene are applied, a panorama of steep clines replaces the regular spatio-temporal gradient - in retrospect, clearly a byproduct of the combined effect of bioturbation, compaction, and old wood dating - that underpinned "wave of advance" views of the spread of farming across Europe (Bernabeu et al. 200I; Zilhão 200I, 2003, 20II; Bernabeu 2006).

The dates of first appearance of domesticates in different regions of Italy, southern France and Iberia are listed in Table 3.22.I, and the sites whence the corresponding evidence comes are those mapped in Map 3.22.I. This evidence shows that it took no more than I50 years for the Neolithic to spread from the Tyrrhenian coast of Italy (where it is documented $\sim 5700 \mathrm{cal}$ BCE by dated barley seeds from the rock shelter of Arene Candide; Binder \& Maggi 200I) to the northern shores of the Alboran Sea, just east of the Strait of Gibraltar (where it is documented $\sim 5550 \mathrm{cal}$ BCE by a dated sheep bone from the cave site of Cueva de Nerja, near Malaga; García et al. 2010). This date is associated with pottery decorated in the same Ligurian style that characterises the earliest pioneer settlements of the Languedoc (Peiro Signado, Pont de Roque-Haute; 


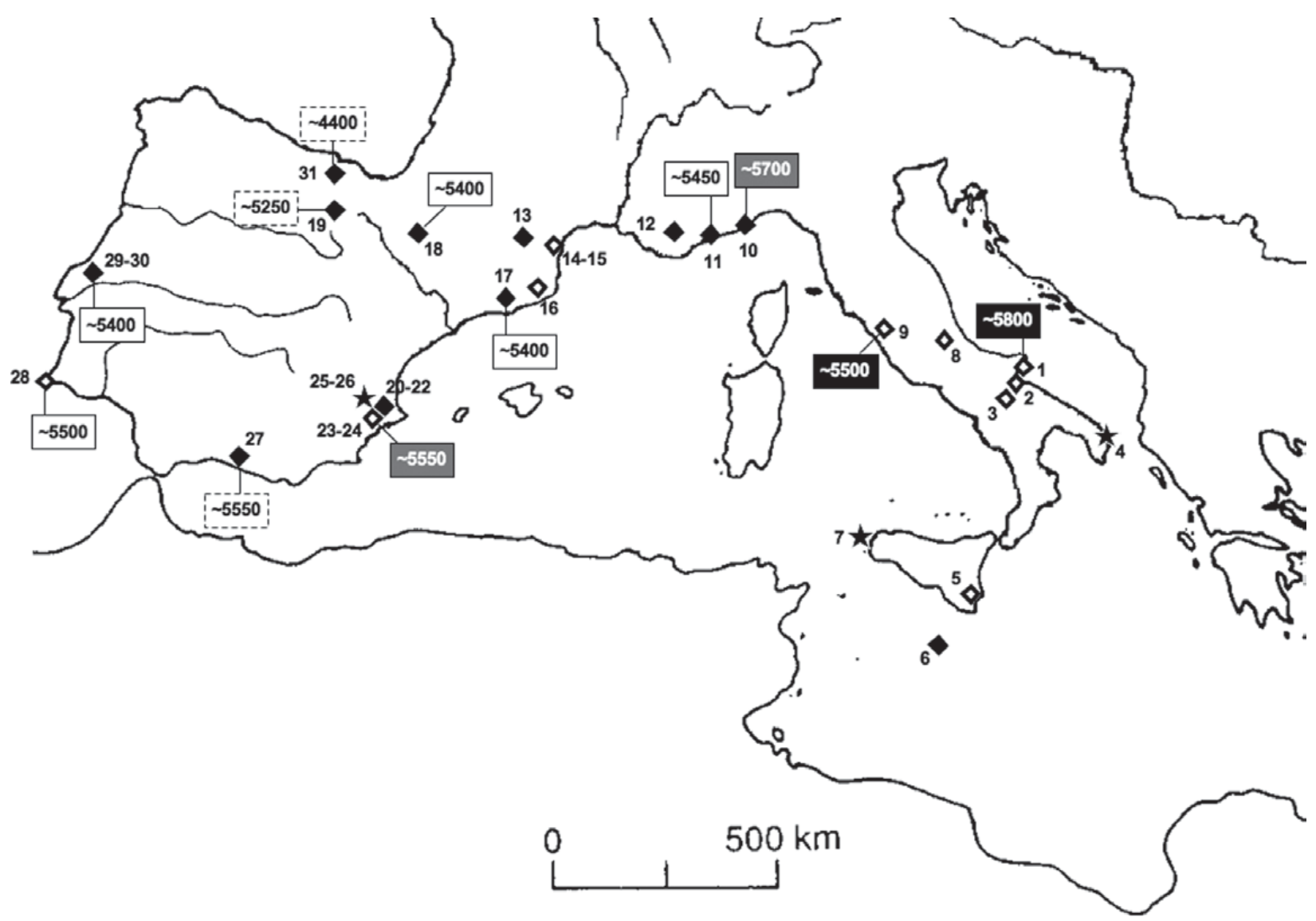

MAP 3.22.I. Early southern European food producers' sites mentioned in the text (black diamonds - cave and rock-shelter sites; open diamonds - open-air settlements; black stars - rock-art sites). The earliest Neolithic dates (rounded to the nearest halfcentury) for the different regions of central and Western Mediterranean Europe are indicated, as is the nature of the associated ceramic wares (black boxes - southern Italian Impressa; grey boxes - Ligurian; white boxes - Cardial; boxes with dashed outline other or uncertain): I. Coppa Nevigata; 2. Passo di Corvo; 3. Rendina; 4. Porto Badisco; 5. Stentinello; 6. Ghar Dalam; 7.

Genovese; 8. San Marco; 9. La Marmotta; Io. Arene Candide; II. Pendimoun; I2. Fontbrégoua; I3. Gazel; I4. Peiro Signado; I5. Pont de Roque Haute; I6. La Draga; 17. Can Sadurní; I8. Chaves; I9. El Mirador; 20-22. Cendres, Or and La Falguera; 23-24. El Barranquet and Mas d'Is; 25-26. La Sarga and Pla de Petracos; 27. Nerja; 28. Cabranosa; 29-30. Cisterna and Caldeirão; 3 I. El Mirón.

Guilaine \& Manen 2007) and of Valencia (El Barranquet, Mas d'Is; Bernabeu et al. 2009), and such pottery is also present in the assemblage from Galeria da Cisterna (Almonda), indicating that the coasts of central Portugal may have been reached at about the same time, and certainly no later than $\sim 5400 \mathrm{cal}$ BCE (Zilhão 2009). A few centuries later, $\sim 5250 \mathrm{cal}$ BCE, sheep and wheat are already present at the cave site of El Mirador, in the upper Ebro Basin (Vergès et al. 2008), but it would take almost another millennium for domesticates to arrive at the shores of the Bay of Biscay, as the earliest Cantabrian evidence comes from a $\sim 4400$ cal BCE grain of wheat found at the cave site of El Mirón (Peña-Chocarro et al. 2005). The rate of spread in the Mediterranean is thus much faster than the I $\mathrm{km} / \mathrm{year}$ predicted under "oil-spill" models of a gradual, overland dispersal of farming caused by short-distance settlement relocation episodes and triggered by slow demographic growth, and such models are also inconsistent with the long period of stasis observed at the Cantabrian boundary.
Therefore, only cultural diffusion (Zvelebil 1986) or maritime pioneer colonisation (Zilhão I993, 2000, 200I, 2003) views of the process remain consistent with the evidence on both the geographical origin of the domesticates and their spatio-temporal pattern of dispersal. The case for cultural diffusion rests on a putative pattern of piecemeal adoption of the different elements of the so-called Neolithic package: cereals, sheep/goats, pottery and polished stone axes. It has been suggested, for instance, that bones of sheep and cattle found in Mesolithic contexts of France and Spain reflected the integration in traditional foraging economies of novel subsistence resources acquired through long-distance exchange networks (Geddes 1983), and that pottery sherds in similar stratigraphic position reflected the independent invention of ceramic vessels prior to the adoption of farming and herding (Alday 2007). But, although the debate is ongoing, the weight of the evidence indicates that (a) the "Mesolithic sheep", all of which come from high-altitude sites, are in fact misidentified ibex and 
chamois (the bones of the three species can be very difficult to tell apart, and especially so those of juveniles), (b) the concept of "Mesolithic cattle" is based upon the misidentification as oxen of bones of female aurochsen, whose size overlaps with that of domestic males, and (c) postdepositional disturbance caused by burrowing and ordinary soil formation processes is the parsimonious explanation for the potsherds and for the remaining cases of genuine domesticates found "out of place" in Pre-Neolithic cave and rock shelter deposits; in short, the evidence is that, in southwestern Europe, the Neolithic did indeed spread as an integrated package (Zilhão I993, 20II).

\section{The mechanism of pioneer expansion}

Human palaeogenetics provides support for an important demic diffusion component in such a spread. A seminal study comparing the mtDNA of human remains from several Mesolithic and Neolithic sites of Portugal with that of modern European populations (Chandler et al. 2005) concluded that the Neolithic sample (a) did not derive directly from Near Eastern farmers but (b) displayed elements of genetic discontinuity with the preceding Mesolithic that implied colonisation at the time of emergence of the Neolithic, presumably from a nearby Mediterranean source. Two subsequent aDNA studies corroborated these findings by showing both the existence of longterm genetic continuity between a later Neolithic sample from Catalonia and modern Iberian populations (Sampietro et al. 2007) and the arrival of small, genetically distinctive groups showing genetic connections with the Near East at the onset of the Neolithic in northeastern Spain (Gamba et al. 2012).

Although not inconsistent with continuity between the Neolithic and the present, the similar studies carried out in central Europe (Haak et al. 2005; Bramanti et al. 2009) yielded a somewhat different picture. Their results were that (a) European ancestry is more complex than the classic dichotomy between "primarily Palaeolithic hunter-gatherers" versus "primarily Neolithic farmers of Near Eastern origin", implying that later prehistoric and early historic events may also have had a significant impact on the genetics of extant Europeans (and, therefore, that extrapolating from present patterns to interpret population dynamics at the Mesolithic-Neolithic transition may not be warranted), and (b) the emergence of food production is associated with a significant genetic discontinuity, with limited exchange of females between resident foragers and immigrating farmers, essentially implying population replacement, as indicated by the absence in the sample of central European early Neolithic people of the $\mathrm{U}_{4}$ and U5 mtDNA haplotypes, to which belonged all the pre-contact Mesolithic individuals from the same region that were analysed (and much the same happened in Sweden too; Malmström et al. 2009). These two U haplotypes, however, are present in both the Mesolithic and the Neolithic samples from Portugal, as well as in the Catalonian Neolithic sample, and the latter also includes individuals of haplotype J, widely considered to be of Near Eastern origin. Combined, these data suggest, for
Western Mediterranean Europe, a process whereby significant levels of interaction with local hunter-gatherer populations followed small-scale settlement by extra-regional groups of farmers and herders, as posited by the maritime pioneer colonisation model.

That early farmers in the Mediterranean were capable of and actually indulged in targeted colonising expeditions involving deep planning and the transportation of groups of people and their cargo over maritime crossings in excess of $100 \mathrm{~km}$ is demonstrated by the settlement of Crete: Broodbank and Strasser (I99I) estimate that a flotilla of ten to fifteen vessels must have been involved in the carrying of the 15 to 20 tonnes required to establish a viable agricultural settlement in that hitherto uninhabited large island (i.e., a group of about forty people with the amount of grain to feed them through the first year and sow the first crop, plus the minimum number of domesticated animals of the different species necessary for a founder population to be genetically viable). Vigne and Cucchi (2005) make a similar argument for Cyprus, first permanently settled by farmers $\sim 9000$ to $8500 \mathrm{cal} \mathrm{BCE} \mathrm{(Manning} \mathrm{et} \mathrm{al.} \mathrm{2010)}$ and to where stocks of both domesticated (sheep, goats, cattle, dogs) and wild (fallow deer and boar) mammals lacking any ancestors in the island were transported at that time over a sea crossing of $\sim 50 \mathrm{~km}$. Moreover, the morphological similarity maintained in the Levant and Cyprus over the subsequent millennia by the populations of domestic mouse introduced alongside indicates sustained genetic flow from the mainland and, therefore, implies a pattern of routine boat traffic in the stretch of sea in between.

Crete and Cyprus have in common their being separated by at least $50 \mathrm{~km}$ from the closest landmasses and their being devoid of permanent human settlement before the Neolithic. As the coasts of both Corsica and Sardinia were inhabited (or at least routinely visited) by Mesolithic hunter-gatherers (Lanfranchi 1998; Costa 2004), the only other island in the Western Mediterranean sharing both these features and sufficiently large to sustain a viable farming community that was settled by early Neolithic people is Malta (Evans 1977; Robb 200I; Malone 2003). Their impressed ceramics, as known from the key cave site of Ghar Dalam, are akin to those of the Stentinello culture of Sicily and Calabria. One may therefore infer from the Maltese case that the mode of expansion implied by the evidence from Crete and Cyprus was also responsible, at least in part, for the establishment of the first farming communities of southern Italy and adjacent islands.

Farther to the west, the coastal location of the earliest Neolithic settlements and the presence of island resources, namely, obsidian from Lipari and Sardinia, in sites from mainland Italy, southern France and Catalonia (Tykot 1997), are also consistent with colonisation via sea routes, but one that followed a different pattern. Ibiza is no more distant from the adjacent Spanish coast than Crete is from the southern tip of the Peloponnese and is separated from Mallorca by a crossing of similar length. Yet the Balearic Islands remained uninhabited until the 3 rd millennium cal BCE (Ramis et al. 2002). Moreover, despite having been found all around the coasts of the Tyrrhenian Sea and the Gulf of Lyon, the obsidian from 
Lipari, which is located off the northern coast of eastern Sicily, is absent from the early Neolithic of Sardinia and Corsica (Tykot 2002). The consistent occurrence, the small amounts and the representation by both cores and blade/bladelet blanks of that obsidian in the French sites indicates down-the-line exchange and/or the movement of persons transporting individual toolkits, in either case implying well-known routes but not a large-scale trade network such as that which distributed finished blanks of Sardinian obsidian to neighbouring regions in later middle Neolithic times (Lugliè 2009). Combined, this evidence is suggestive of a navigation by cabotage (i.e., over coastal waters and involving short mainland-island or islandisland crossings but not targeted landfalls in far-away locations across open seas), and implies that the Neolithic package spread around the $\sim 2250 \mathrm{~km}$ of a cabotage route from Rome to Malaga at a rate of $\sim$ I5 $\mathrm{km} /$ year.

Direct evidence of the existence at this time of vessels sufficiently seaworthy for such a navigation is provided by the > 10 m-long dugout canoe found in 1993 in the submerged lakeside dwelling of La Marmotta, near Rome, where coupled tree-ring and radiocarbon dating of house posts places the occupation in the middle of the 6th millennium cal BCE (Fugazzola-Delpino et al. 1993; Fugazzola-Delpino \& Mineo I995; Kromer 2009). Five years later, a replica built by Czech archaeologists was taken from Sicily to Portugal (Tichý 200I), and one can easily see how this transportation technology could have been quite effective for the moving around of substantial amounts of cargo simply by fastening two such canoes with planks to form a catamaran akin to those used a few millennia later by the Stone Age farmers who colonised islands of the Pacific separated by sea crossings several times longer than those involved in the Western Mediterranean story (Irwin I992). Moreover, many ethnographic examples exist to show that, in calm seas, rafts capable of transporting 150 to $200 \mathrm{~kg}$ of cargo suffice to move around over short distances the number of humans and the amount of grain and live animals necessary to form a pioneer agricultural settlement (Vigne \& Cucchi 2005). If we bear in mind the archaeological evidence from the Languedocian site of Pont de Roque-Haute, strongly suggestive of it having been a beachhead for people coming directly from Italy, these pioneer colonists may have enhanced the chances of success by travelling as light as possible, namely, by reducing the range of initially transplanted animals to only sheep and goats (Guilaine \& Manen 2007; Tresset \& Vigne 2007).

In the Western Mediterranean, such small-scale dispersals would also have been facilitated by the hunting of wild game as a supplementary resource (a possibility that did not exist in the large islands with an endemic Pleistocene megafauna, because either it had already gone extinct or its behavioural features, linked to lack of predators and low reproductive rates, entailed extremely rapid extinction under human predation) and by the presence of forager groups with whom symbiotic relationships could be established, namely, via networks of exchange through which to procure the supply of the extra resources and extra personnel required to secure the long-term success of the pioneer settlements. Under such a scenario, one would expect (a) the presence in the descendant populations of both farmer (ultimately, Near Eastern) and forager genetic inputs, as indeed happens in Iberia, (b) the circulation of goods across the territories of both farmers and foragers, as indeed intimated by flint provenance studies in Liguria and Provence (Binder \& Maggi 200I) and (c) the eventual absorption of the local foragers by the pioneer farming groups, as a result of the significantly higher productivity and, hence, higher potential for demographic growth of food-producing economies (which, by simplifying the ecosystem, can extract a lot more energy per unit of territory).

Once the pioneers settle and thrive, the outcome of the process is therefore predictable, so the key to understanding it lies in the conditions under which the mechanism can be set in motion, which essentially involve the twin issues of "land availability" and "locals' consent". The cultural geography of the emergence of farming in littoral-central Portugal provides the best illustration of how the mechanism could and did work (Zilhão I993, 2000, 200I; Lubell et al. I994; Map 3.22.2). Its earliest Neolithic is of an enclave nature, as it occupies territories abandoned by late Mesolithic hunter-gatherers after $\sim 6500 \mathrm{cal}$ $\mathrm{BCE}$, at a time when, with the onset of the Atlantic climatic optimum and the ensuing increased density of local forests, their settlement and subsistence strategies were reoriented towards the rich riverine ecotonal areas surrounding the vast estuaries of especially the Tagus and the Sado rivers. The possession of sheep and the terrestrial diet evidenced by analysis of the stable isotopes of carbon and nitrogen extracted from human bone indicate that this enclave is truly Neolithic in the economic, not just the artifactual sense of the word, and the similarities in styles of ceramic decoration and types of personal ornaments with contemporary sites in the Gulf of Valencia indicate a rapidity of expansion that implies long-distance colonisation and that large voids would have been left behind in the process. Such voids do exist, and correspond precisely to the areas where the late Mesolithic is documented - by a system where as much as $50 \%$ of the diet came from fish and shellfish and that persisted virtually unchanged for about five centuries after the first Neolithic settlements became established in the limestone massifs to the north and to the south. The Mesolithic shell-mound habitation sites and the hundreds of burials they contain indicate, in fact, that very little, if anything, of the material culture novelties brought by the Neolithic settlers was adopted - pottery, polished hand axes and heat-pretreated flints have never been recovered, nor have any of the burials directly dated to the postcontact period ever yielded the kinds of personal ornaments (tear-shaped shell beads, pierced red deer canines and bone beads imitating their shape) that are most common in funerary contexts of the coeval, adjacent earliest Neolithic. Thus, the marked contrasts in culture, subsistence and ritual show that the earliest Neolithic settlement of central Portugal does not represent an expansion into new areas of personnel derived from the local estuarine Mesolithic stock (with the economic and technical adaptations made possible by the acquisition, via long-distance exchange, of cereals and sheep), and that the two systems remained largely independent throughout the long interval during which they developed side-by-side, with exchanges probably limited to 


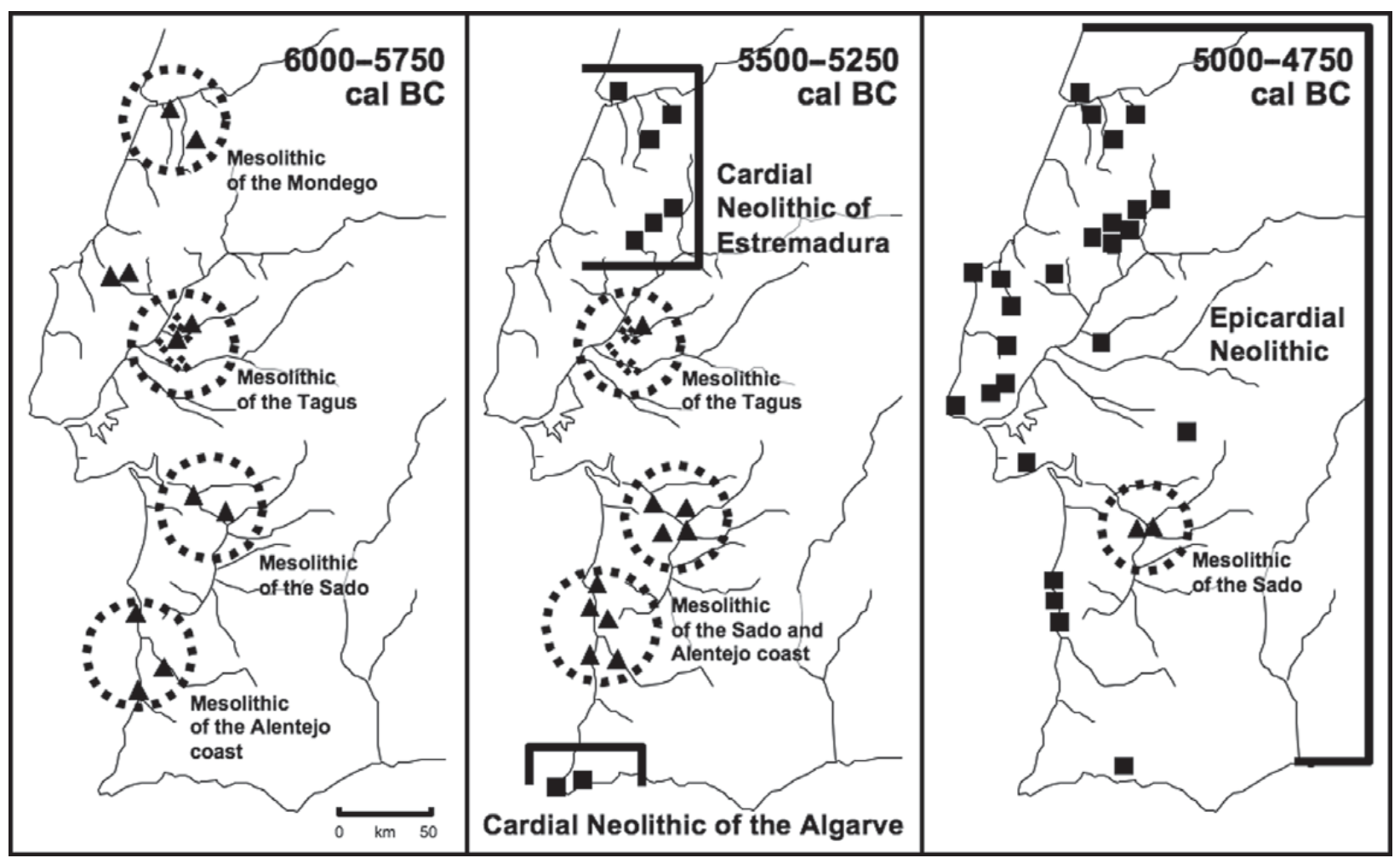

MAP 3.22.2. Geographic distribution of Late Mesolithic (triangles) and Early Neolithic (squares) settlements in South-central Portugal between 6000 and 4750 cal BCE. (From Zilhão 200I.)

raw-materials, perishable items (e.g., foodstuffs) and, at least occasionally, marriage partners.

This example makes it clear that (a) Neolithic pioneers in search of new land to found farming settlements did indeed have such land available to them on the European mainland, not just in the islands uninhabited by Mesolithic huntergatherers, and (b) initial settlement could occur without conflict and perhaps even with limited contact because of the mutually exclusive nature of the land needs of pioneer farmers (light soils in dry terrain and forests that could be cleared for sheep/goat grazing) and resident hunter-gatherers (coastal and riverine areas rich in aquatic resources complemented by game from the adjacent woodlands). Although the evidence is not as clear-cut as in Portugal, due to the paucity of late Mesolithic sites and the limitations of the available corpus of radiocarbon dates, a model of pioneer Neolithic enclaves that exclude the littoral wetlands areas exploited by the fisher-hunter-gatherers of the Atlantic period is also suggested by site distribution patterns around the Gulf of Genoa (Binder \& Maggi 200I; Biagi 2003), where the virtual lack of Castelnovian (latest Mesolithic) occurrences suggests either depopulation or, as in Portugal, a concentration in waterfront locations (that, in littoral northern Italy, may have been lost due to sea-level rise). In contrast, the rather continuous distribution of Mesolithic sites in the narrow coastal strip situated to the north of the Cantabrian Mountains makes it difficult to envisage a spread of the Neolithic via the same mechanism (Arias 2007). In this part of Iberia, alternative scenarios are therefore more likely; for instance, an adoption of the Neolithic package by local hunter-gatherers in reaction to a situation of extreme stress brought about by the very high sea levels recorded $\sim 4300$ cal BCE (González-Morales I992), or the spread, via low passes located in the western Basque country and triggered by the reaching of a demographic threshold, of the Neolithic communities established across the mountains to the south, in the upper Ebro Basin, since almost a millennium earlier (Rojo et al. 2008).

\section{Material culture and ways of life}

The artifactual hallmark of early food production in Italy, France and Iberia is of course the pottery (Fig. 3.22.I). In southern Italy, painted wares perhaps of ultimate Greek tradition also exist, but most early Neolithic ceramics are decorated with a range of impressed motifs. Although the issues of site formation that plague the dating of the neolithisation process (postdepositional disturbance and palimpsest formation, which affect not just cave and rock shelter sites but also those in the open that were inhabited for long periods of time and where the evidence comes mostly from negative features, such as ditches) also complicate the sorting out of detailed ceramic stratigraphies, a broad picture of the succession is now available for at least the West Mediterranean (Binder \& Maggi 200I; Bernabeu et al. 2009). The initial phase, in the so-called Ligurian style, features flat-bottom, flower pot 


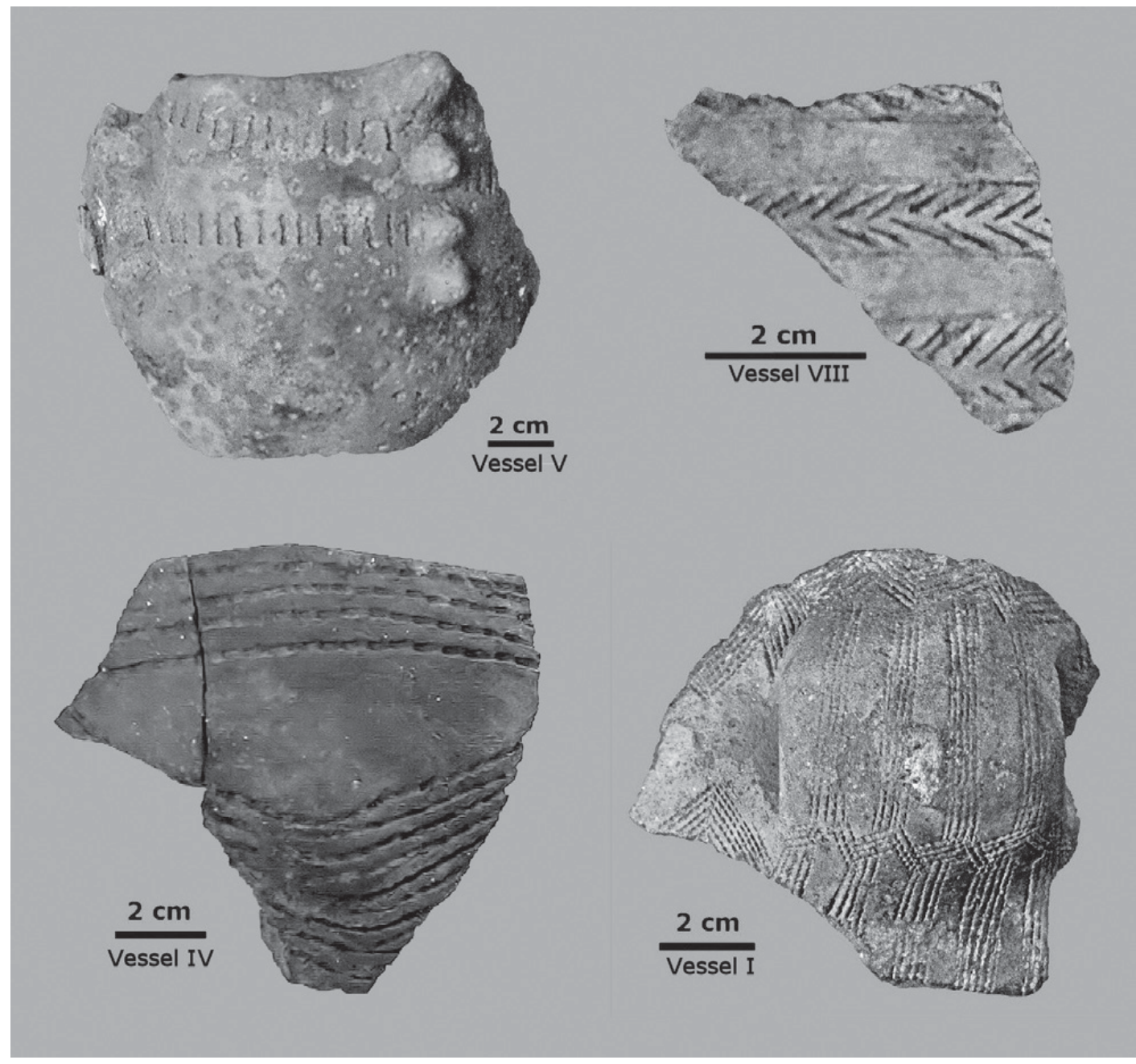

Figure 3.22.I. Early Neolithic ceramic styles of Western Mediterranean Europe (vessels from Galeria da Cisterna, Almonda, Portugal): vessel IV, Ligurian Impressa (impressed groove) style; vessel I, early Cardial style; vessel V, late Cardial style; vessel VIII, Epicardial style.

shapes, associated with carafes and spherical bowls and decorated with a range of shell-, finger- and nail-impressions made before firing, among which the so-called impressed groove (sillons d'impressions) technique is especially diagnostic. The subsequent phase, in the Cardial style, begins $\sim 5400 \mathrm{cal}$ вСе, keeps the shapes of the previous one, except for the flat bottoms, features handles, knobs and cordons of different types, and is characterised by the use of the cockle shell (hence the style's name, derived from the old scientific name of the species, Cardium edule) to produce decorative patterns organised in discrete zones, sometimes covering the entire vessel but more often than not forming horizontal bands restricted to the area below the rim or extending down from it as garlands. The earliest dates for the Cardial are statistically the same from the Gulf of Genoa to central Portugal (Map 3.22.I), suggesting that networks of communication and exchange encompassing the entire Western Mediterranean were maintained long after the initial pioneer phase. After $\sim 5000 \mathrm{cal}$ BCE, the area then witnesses the development of a multiplicity of regionally differentiated, so-called Epicardial styles in which the cockle shell is almost completely replaced by other tools, and impressions are associated with incision and postfiring excision to form more varied, although in general less baroque decorative patterns. Provenance studies (e.g., Barnett, I990) suggest that the point of deposition or discard of the utilitarian ceramics, often undecorated, is either within or in the neighbourhood of the production area, reflecting local consumption or small-scale transport within the boundaries of individual social territories. The more carefully finished and highly decorated impressed wares, however, were circulated over longer distances and may have been involved in gift giving and in ritual or prestige exchange activities.

The Cardial Phase of Mediterranean Spain is also characterised by the emergence of a range of bone and antler tools that are unknown in the local Mesolithic (which, however, may well have possessed versions of them made of perishable wood), such as spoons and spatulas. And in the rare instances of submerged lakeside dwellings where wood and fibre are preserved, we have a glimpse of the wider range of these pioneers' tools and containers: for instance, at La Draga, in 
Catalonia, sickles and adze handles, digging sticks, arrows, bows and baskets (Tarrús 2008). With regard to personal ornaments, marine shell beads predominate, but the bone and teeth of mammals as well as a range of rocks and minerals, namely, limestone, calcite, marble and schist, were also used for the manufacture of bracelets and of discs, rings and pendants of diverse shapes, in all likelihood parts of composite beadworks (Fig. 3.22.2). These materials tend to be locally procured for the most part, although the metamorphic rocks used in the manufacture of stone bracelets from the Cardial of Valencia come from sources in Andalucia, $\sim 300 \mathrm{~km}$ away (Harrison \& Orozco 200I); eventually, regular trade networks encompassing even longer distances emerge in the Epicardial for the distribution of a range of green rocks (often designated collectively as callaïs but for the most part variscite) widely used at this time in the production of beads (Villalba et al. 1986). Good quality raw materials for knapped stone toolmaking are largely absent from the kinds of terrain settled by the pioneer farmers in southeastern France and northwestern Italy, explaining the pattern of long-distance circulation of flint from the Alps and the Apennines, procured via exchange networks involving hunter-gatherer groups still living in those areas. The reverse is true for the hard green rocks used in the manufacture of axe and adze blades, which are part of the Neolithic package from the very beginning and have sources close to the Gulf of Genoa's main clusters of early Neolithic sites, a factor that may have weighed significantly in determining the choice of location for the founder settlements (Binder \& Maggi 200I). In southern and western Iberia, however, no sources of suitable green rocks, namely amphibolite, exist in the littoral areas (Lillios 1997), and their procurement may well have prompted precocious upriver exploration by the pioneer Neolithic settlers of a hinterland (the Mesetas) that seems to have become devoid of human settlement at the end of the Boreal Period, if not before.

Where subsistence is concerned, the vagaries of preservation and recovery only allow a partial picture of the range of plants that were cultivated and consumed, and of the mode of their exploitation. A recent survey (Rottoli \& Castiglioni 2009) shows that little difference exists between the early Neolithic evidence from northern Italy and that from central Europe and the Balkans, and much the same can be said for Iberia (Bosch et al. 2005): barley and emmer, einkorn and bread wheat represent the cereals; lentils, peas and fava beans are the most common pulses; and hazelnut, wild apple, blackthorn, plum, wild grape and a range of berries document the collection of wild fruits. A contrast seems to exist, however, in the composition of the animal herds, with cattle, raised for meat and secondary products (probably milk) predominating in Greece and southern Italy (in terms of overall animal weight, if not number of individuals), and sheep/goats in southern France and Iberia (Vigne \& Helmer 1999; Tagliacozzo 2005). In a group of three sites in Provence, the slaughtering profiles of caprines show a concentration in the six-to-twelve-month age class, indicative of an exploitation primarily for meat, although the relatively high proportion of individuals less than two months old in some assemblages suggests culling of newborns to secure access to the mothers' milk. Game is also very important in many of the southern French and northern Italian sites, where the remains of wild animals (e.g., deer and boar) are sometimes more abundant than those of domesticates. This observation, however, needs to be understood against a research history that biases the comparisons. In southern Italy, the evidence comes mostly from open-air village settlements (e.g., Rendina and Passo di Corvo, in the Tavoliere Plain of Apulia), while in Liguria, Provence and the Languedoc it comes almost exclusively from cave and rock shelter sites (e.g., Arene Candide, Fontbrégoua, Gazel) that represent only a fragmentary part of the overall Neolithic settlement system - specialised hunting camps and penning stations used in the framework of an incipient caprine transhumance from low ground in the winter to high ground in the summer. The evidence from La Draga and other coeval open-air Catalonian sites is in this respect quite telling, as they show that, in the Cardial Phase, bovines, exploited for meat, milk and milk products, were economically more important than sheep/goats (Piqué 2005). Where the latter predominate, the reason is therefore likely to be either the very early age of the site (reflecting the constraints of pioneer settlement) or its specialised, logistical nature.

That, as in southern Italy and the Eastern Mediterranean, early Neolithic life in the Tyrrhenian Sea and to the west was organised around villages formed by clustered huts and associated constructions and bringing together several families to form population agglomerates of several tens or even hundreds of persons is documented by the few instances where the evidence comes from well-preserved open sites. At La Marmotta, about three thousand oak posts, scattered over an area of $\sim 2$ ha, give an idea of the size of the settlement, which may have been occupied by as many as five hundred people living in rectangular houses, on average 6 by $8 \mathrm{~m}$; those already excavated form a single street interrupted at right angles by little alleys, suggesting the existence of some form of organised village layout (Fugazzola-Delpino et al. 1993; Kunzig 2002). At La Draga, treering analysis of the almost nine hundred oak posts recovered shows that the site was used for at most one hundred years, and perhaps no more than forty, and that two rows of IO-I2 by 3-4 $\mathrm{m}$ rectangular huts, raised about one metre above the water and separated by an empty space or street, ran along the lake margin; on dry land, about $60 \mathrm{~m}$ upslope, several small, hut-like oval constructions were probably used as granaries (given the large amounts of burnt remains of cereals and pulses found therein), and the overall abundance of fava bean remains in the deposits suggests that gardens for the cultivation of pulses occupied the intervening space (Tarrús 2008).

The site of Mas d'Is (Alicante, Spain), in the headwaters of the Serpis River, provides a rare glimpse of the aspect of such settlements when located on dry ground. The earliest occupation, dating back to the pioneer colonisation phase, $\sim 5550 \mathrm{cal}$ $\mathrm{BCE}$, is represented by a single house, but in the Cardial Phase, $\sim 5400 \mathrm{cal}$ ВСE, two other houses were built in the same area, one of which with a largely rectangular outline (and an apse at the preserved end) indicated by post-holes that demarcate a 4-m-wide living space preserved over a length of ro $\mathrm{m}$. Some $200 \mathrm{~m}$ away from the settlement, a circular causewayed ditch, 


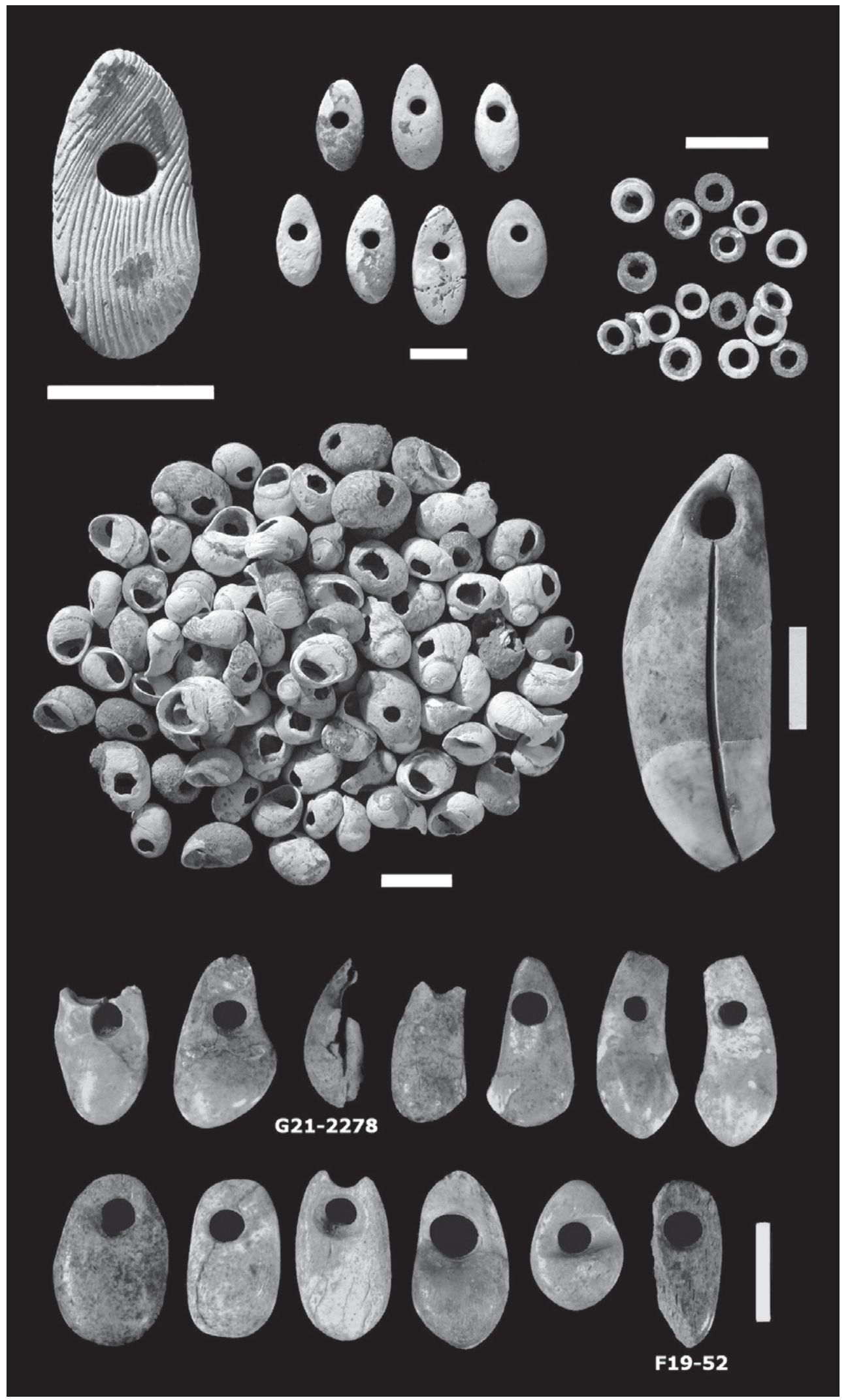

Figure 3.22.2. Early Neolithic ornaments from the Galeria da Cisterna, Almonda (all scale bars $=\mathrm{I} \mathrm{cm}$ ). Top row, left to right: oval pendant made on cuttlefish shell (Sepia officinalis); seven oval pendants made on Glycymeris sp. shells; discoidal limestone beads. Middle row, left to right: Theodoxus fluviatilis shell beads; pierced wolf canine. Bottom row: pierced red deer canines and bone pendants imitating their shape (the two radiocarbon-dated specimens are indicated by the corresponding inventory numbers) (from Zilhão 2009); photos J. P. Ruas (top and middle rows) and F. d'Errico (bottom row).) 

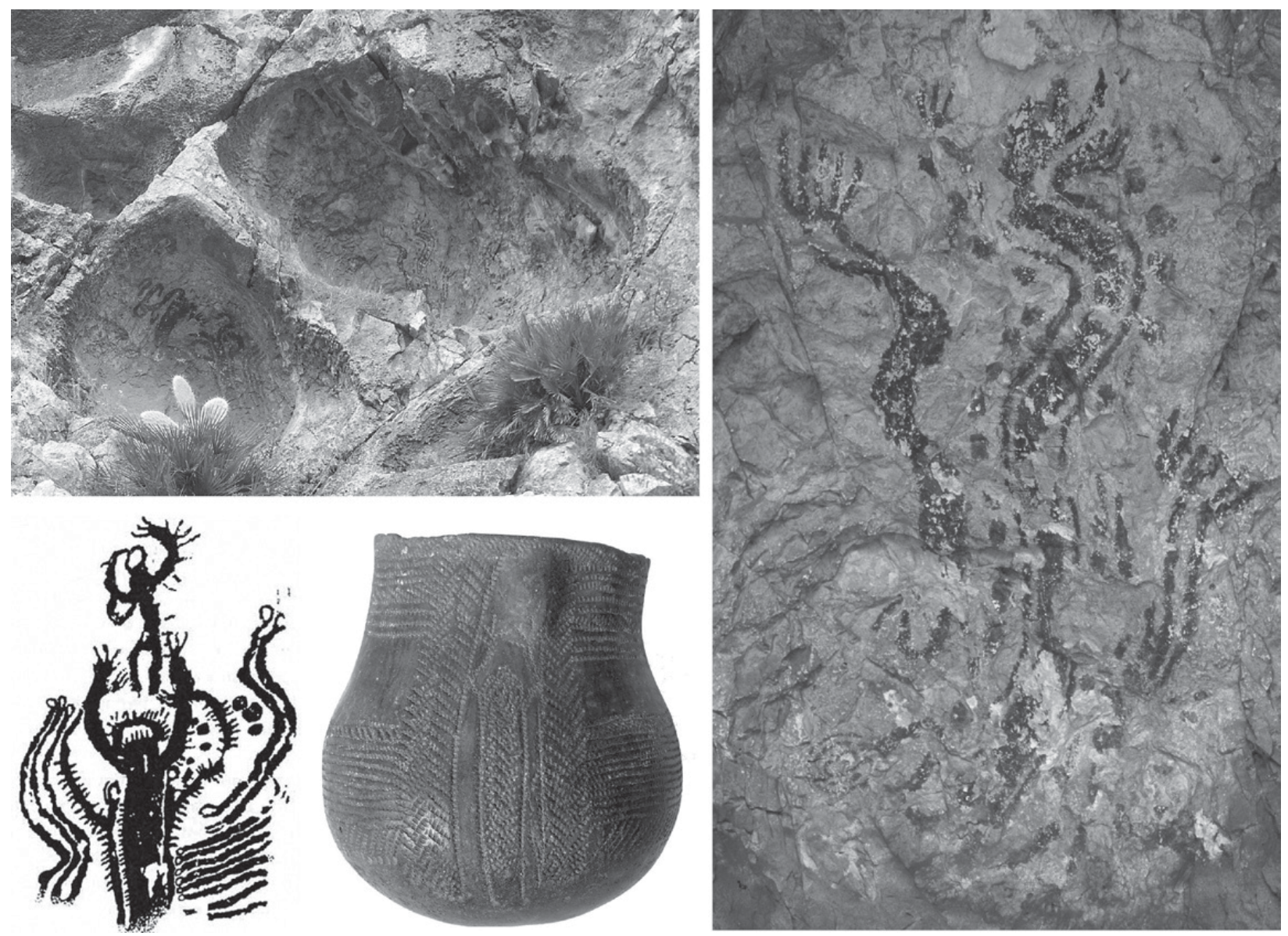

Figure 3.22.3. Early Neolithic rock art (macroschematic anthropomorphs). Top left, two decorated panels from Pla de Petracos (photo courtesy M. Hernández). Bottom left, anthropomorphous figures from Pla de Petracos (tracing M. Hernández) compared with that in the decoration of a Cardial pot from Cova de l'Or (height $15.2 \mathrm{~cm}$; photo J. Piqueras and L. Pizá, Museu Arqueològic Municipal de Alcoi). Right, close-up view of a panel from Pla de Petracos. (Photo courtesy M. Hernández.)

$U$-shaped in cross section, $\mathrm{I} 2 \mathrm{~m}$ wide and $3.5 \mathrm{~m}$ deep, bounded an area of $\sim$ I ha that was not part of the inhabited space and seems to have been reserved for ritual activities (Bernabeu et al. 2003). Radiocarbon dating shows that this feature (Ditch 5) was built no later than $\sim 5400 \mathrm{cal} \mathrm{BCE}$, and it is estimated that about 65,000 hour/persons were required to excavate it, which, for a settlement of about one hundred people, could have been accomplished in less than three months; this implies the possibility of bringing together the co-ordinated work of an entire community but needs not implicate the existence of social ranking or a chiefdom-like power structure. The excavators of Mas d'Is argue that the short distance between the village and the causewayed precinct is suggestive of rituals related to daily life, and that burial and more complex, perhaps intercommunity religious activities would take place at special sites located farther out. Ligurian and Cardial burials are very rare, but the few cases known - such as Pendimoun, in Liguria (Binder et al. 1993), or Cisterna and Caldeirão, in Portugal (Zilhão 1993, 20II) - are indeed in caves and rock shelters that either were never used for habitation or had become abandoned at the time of funerary use. The rock art sites in the so-called macroschematic style (e.g., La Sarga and
Pla de Petracos), restricted to southern Valencia, in the general area of the region's earliest Neolithic settlement (which also includes cave and rock shelter sites such as Cova de l'Or, Cova de Cendres and Abric de La Falguera), exemplify another type of religious place, and the style's characteristic, large-sized anthropomorphous motifs (Fig. 3.22.3), replicated in ceramic vessels of the Cardial Phase, indicate contemporaneity with that settlement (Martí \& Hernández i988; Hernández 2006).

That rock art was indeed part of the culture of southern Europe's early food producers is further indicated by the Italian painted caves of Porto Badisco (Apulia) and Grotta del Genovese (on the island of Levanzo, off western Sicily), although the parallels in ceramic decoration suggest in these cases a middle or later Neolithic age (Malone 2003). Although once thought to be Late Palaeolithic or Mesolithic, because of the naturalistic style and preponderance of hunting scenes, the so-called Levantine paintings of Mediterranean Spain must also be of middle or later Neolithic age, given the pattern of superimposition over macro-schematic motifs observed at a number of sites, most evidently at La Sarga (Hernández \& Martí 2000-I). It is also at this time, after $\sim 4000 \mathrm{cal}$ BCE, that architecture on an imposing scale begins to dot the agricultural landscapes of the Central 


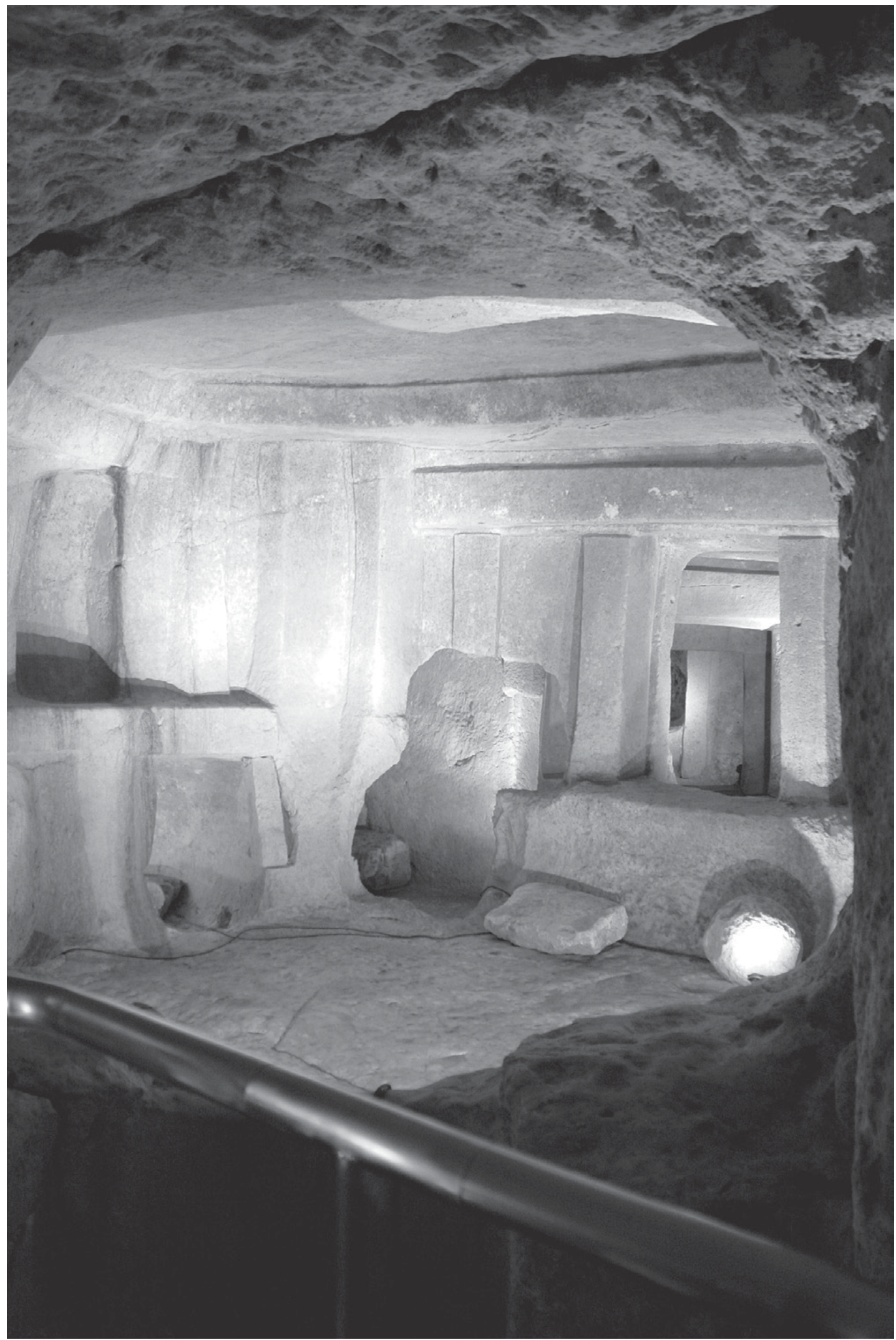

Figure 3.22.4A. The Hal-Saflieni hypogeum (Malta). (Photo Caroline Malone.) 


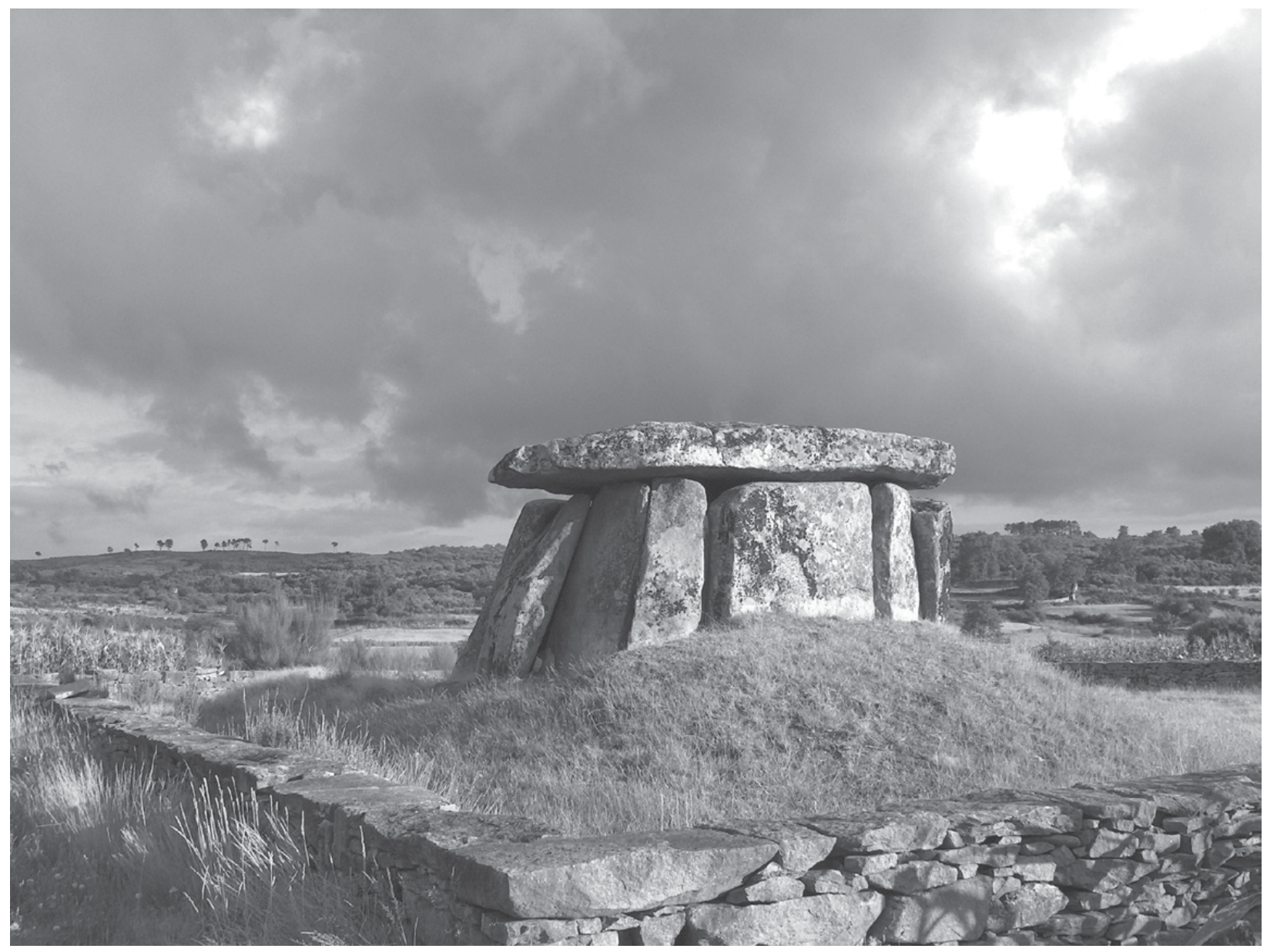

Figure 3.22.4B. The Orca de Pendilhe dolmen (Vila Nova de Paiva, Portugal) (http://commons.wikimedia.org/wiki/File:Anta_ orca_de_pendilhe_0486.JPG; author: João Carvalho; copyright: licensed under the Creative Commons Attribution-Share Alike 2.5 Generic license).

and Western Mediterranean (Figs. 3.22.4a and 3.22.4b). Mostly, these developments concern places for the dead (e.g., rock-cut tombs, beehive-like catacombs, dolmens, passage graves), but the so-called megalithic phenomenon (i.e., the construction of monuments with very large stones, standing alone or interlocked without mortar) also includes features designed for the rituals of the living (e.g., menhirs, cromlechs, alignments). As best seen in the Maltese case (Robb 200I), this monumentalisation arose in the context of the continued existence of long-distance exchange and contact, but largely as a result of endogenous social processes, not of the putative immigration of new "megalith-building" peoples.

The construction of small-chamber tombs covered by large cairns, involving substantial amounts of collective work but where only a single person is buried, often in association with prestige artefacts, hints at the emergence of distinguished individuals, something for which no evidence exists in the preceding Early Neolithic. Whether such distinction can be taken as a proxy for the emergence of social hierarchy or of hereditary chiefdoms is, however, an unresolved issue, but that a caste of professional priests may have existed in the final phases of the Maltese process, after $\sim 3500 \mathrm{cal} \mathrm{BCE}$, has been surmised on the basis of the large size and complexity of such underground sanctuaries as Hal-Saflieni (with three levels, built in different phases, and covering about $500 \mathrm{sq} \mathrm{m}$ ), where some of the nonfunerary halls contained statues of female deities indicative of some form of organised religion (Guilaine 2003). However, the fact that the funerary parts of Hal-Saflieni contained the remains of about seven thousand people strongly suggests that access to burial in such a special place was universal, hinting at communities closely knit by kinship ties and little, if any, social stratification. On the other hand dolmens and passage graves often contain too few individuals (mostly ranging from a few to a hundred) to be considered as the burial place of entire communities that, over the period of use, must have generated significantly larger numbers of bodies. Whether this means that such monuments were reserved for a particular stratum or a particular segment of the population remains an open issue but, in southwestern Iberia, the megalithic tombs contain artifacts that, as in Malta, hint at the importance of kinship in determining the social identity of people - the engraved schist plaques (Fig. 3.22.5), which, when found in situ, are associated with single skeletons and present a variation in decorative patterns indicative of their being heraldry items, recording lineage affiliation and genealogical distance from an important ancestor (Lillios 2002, 2008). 


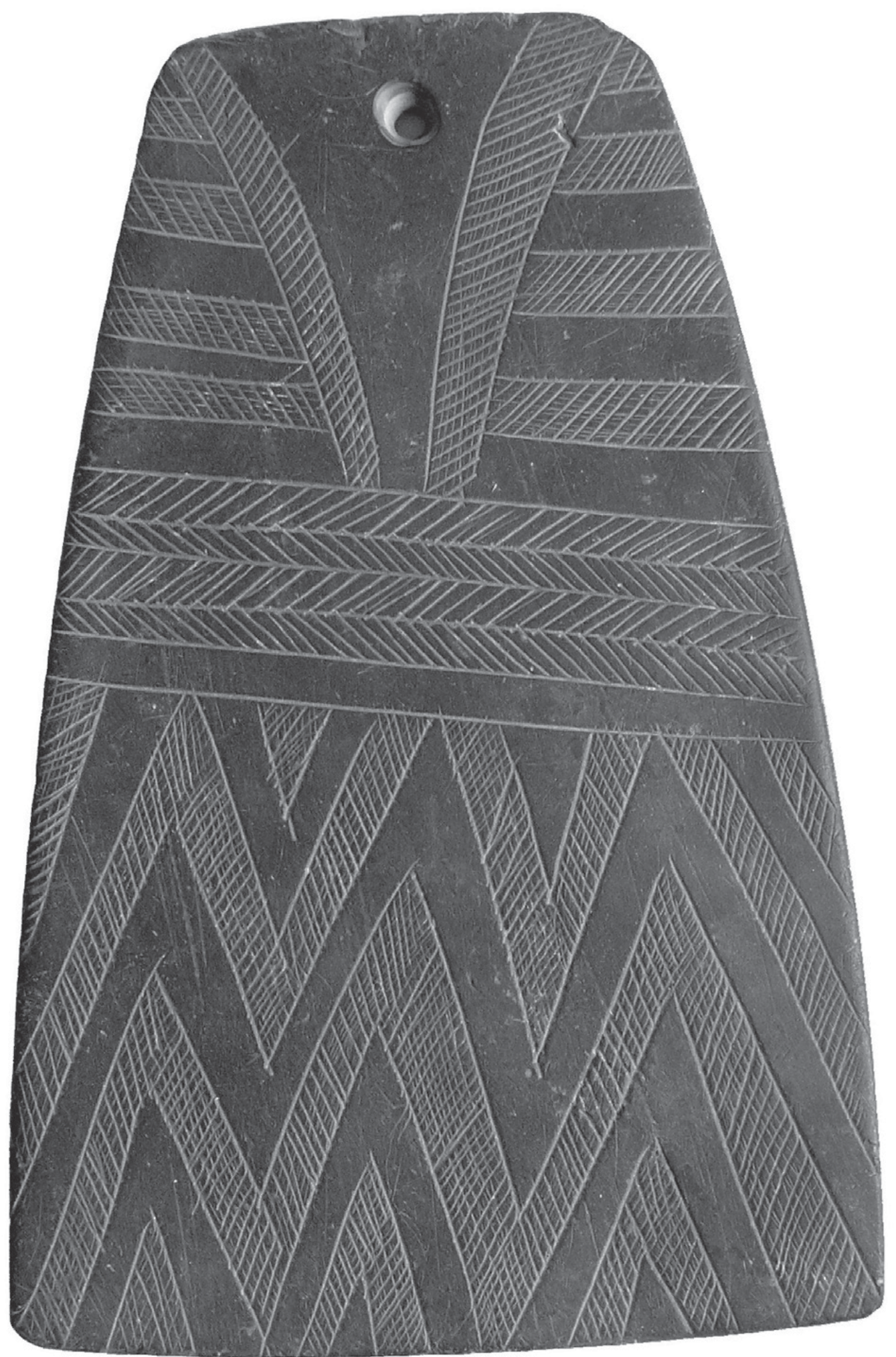

Figure 3.22.5. A schist plaque (height $\mathrm{I} 6.6 \mathrm{~cm}$ ) from the Anta do Olival da Pega dolmen (Évora, Portugal). (Courtesy K. Lillios.) 


\section{Concluding Remarks}

The emergence of food production in Central and Western Mediterranean Europe is therefore rather akin to the mechanism known in evolutionary biology and biogeography as an adaptive radiation. The rapidity of the spread and attendant fill-up of the totality of the available niche - the littoral areas of limestone terrain within reach of cabotage routes and featuring a Mediterranean climate, whose northernmost limit, the mouth of the Mondego River in Portugal, coincides with that of the distribution of the pioneer Neolithic settlers characterised by pottery decorated in the Ligurian and Cardial styles are matched by the ensuing drift manifested in the diversity of the later Epicardial productions. What remains to be clarified is the reason why such a rapid expansion occurred in the first place, as it is clear that, within one or two generations, that is, long before the carrying capacity of the territories of newly established settlements had been reached or even approached, groups of pioneers were again budding off from them to create new colonies. One possibility (Zilhão 200I) is that such a tendency to stay small and move on was deeply rooted in tradition and ultimately relates to the events that brought about the collapse of the Levantine PPNB. As pointed out by Özdogan (I997), these societies were characterised by social stratification and strongly developed cult practices, while those that followed, and with which food production eventually spread westwards into the Balkans and, eventually, central Europe, Italy, France and Iberia, lack specially built temples and feature no evidence of ranking in settlement or in burial. An ethos of fissioning before groups became too large and severe internal conflict or social inequality could develop may thus underpin the Neolithic radiation into Europe, and in particular the maritime pioneer settlement of the Western Mediterranean.

This mechanism could go on functioning for as long as the vast early Holocene forests of the continent presented a seemingly endless supply of new land but, eventually, demographic growth had to lead to densification and attendant social consequences. Archaeologically, this is reflected in the change that takes place across southwestern Europe after $\sim 4000 \mathrm{cal}$ BCE from the diffuse (and lacking in conspicuous monuments) settlement-network of the Early Neolithic to a landscape of large collective tombs that probably also functioned as symbols of ownership of territories with well-defined boundaries. These developments mark the beginning of the gradual process of social complexification that ultimately generated the stratified societies of the Copper Age and early Bronze Age which built the nuraghi of Sardinia, the talayot of Mallorca and Menorca, and the fortified hilltop settlements of Andalucia (e.g., Los Millares) and Portugal (e.g., Zambujal).

\section{Acknowledgements}

The preparation of this text benefited from the assistance of a number of colleagues, who read preliminary versions, contributed information and useful comments, or supplied illustrations. I wish to acknowledge in particular the help of Emili Aura, Joan Bernabeu, Maria Antonietta Fugazzola Delpino, Mauro Hernández, Katina Lillios and Mauro Rottoli, and recall the enormous work of the organisers of the Conferences on the Iberian Neolithic held in Gavà, Valencia, Santander and Alicante every three or four years since 1995 . It is thanks to their efforts that the great progress made over the last twenty years in our knowledge of a key region for the understanding of early food production in Europe could be brought together and disseminated to the wider profession as a voluminous collection of many thousands of pages of proceedings that are a treasure trove of information.

\section{References}

Alday, A. 2007. Mésolithique et Néolithique au Pays Basque d'après l'abri de Mendandia (8500-6400 вP): l'évolution de l'industrie lithique, le problème de la céramique et les stratégies d'occupation. L'Anthropologie III: 39-67.

Ammerman, A. J. \& Cavalli-Sforza, L. L. I973. A population model for the diffusion of early farming in Europe, pp. 343-57 in (C. Renfrew, ed.) The Explanation of Culture Change. Models in Prehistory. Duckworth: London.

1984. The Neolithic Transition and the Genetics of Population in Europe. Princeton University Press: Princeton, NJ.

Arias, P. 2007. Neighbours but diverse: social change in northwest Iberia during the transition from the Mesolithic to the Neolithic (5500-4000 cal BC). Proceedings of the British Academy I44: 53-7I.

Barnett, W. K. I990. Small-scale transport of early Neolithic pottery in the west Mediterranean. Antiquity 64: 859-65.

Bernabeu, J. 2006. Una visión actual sobre el origen y difusión del Neolítico en la Península Ibérica. Ca. 5600-5000 cal. a.C., pp. I89-2II in (O. García \& E. Aura, eds.) El Abric de La Falguera (Alcoi, Alacant). 8.000 años de ocupación humana en la cabecera del río de Alcoi. Diputación Provincial/Ayuntamiento/Caja de Ahorros del Mediterráneo: Alicante and Alcoy.

Bernabeu, J., Barton, C. M. \& Pérez, M. 200I. A taphonomic perspective on Neolithic beginnings: theory, interpretation, and empirical data in the Western Mediterranean. Journal of Archaeological Science 28: 597-6I2.

Bernabeu, J., Molina, L., Esquembre, M. A., Ramón, J. \& Boronat, J. D. 2009. La cerámica impressa mediterránea en el origen del Neolítico de la península Ibérica? pp. 83-95 in (Collectif) De Méditerranée et d'ailleurs ... Mélanges offerts à Jean Guilaine. Archives d'Écologie Préhistorique: Toulouse.

Bernabeu, J., Orozco, T., Díez, A., Gómez, M. \& Molina, F. J. 2003. Mas d'Is (Penáguila, Alicante): Aldeas y recintos monumentales del Neolítico Inicial en el valle del Serpis. Trabajos de Prehistoria 6o (2): 39-59.

Biagi, P. 2003. A review of the Late Mesolithic in Italy and its implications for the Neolithic transition, pp. 133-55 in (A. J. Ammerman \& P. Biagi, eds.) The Widening Harvest. The Neolithic Transition in Europe: Looking Back, Looking Forward. Archaeological Institute of America: Boston.

Binder, D. I995. Éléments pour la chronologie du Néolithique Ancien à céramique imprimée dans le Midi, pp. 55-65 in (J.-L. Voriz, ed.) Chronologies néolithiques. De 6000 à 2000 avant Notre Ėre dans le Bassin Rhodanien. Société Préhistorique Rhodanienne: Ambérieu-en-Bagey. 
Binder, D., Brochier, J.-E., Duday, H., Helmer, D., Marinval, P., Thiébault, S. \& Wattez, J. I993. L'Abri Pendimoun à Castellar (Alpes-Maritimes): Nouvelles données sur le complexe culturel de la céramique imprimée méditerranéenne dans son contexte stratigraphique. Gallia Préhistoire 35: 177-25I.

Binder, D. \& Maggi, R. 200I. Le Néolithique ancien de l'arc liguro-provençal. Bulletin de la Société Préhistorique Française 98 (3): 4II-22.

Blasco, A., Edo, M. \& Villalba, M. J. 2005. Cardial, epicardial y postcardial en Can Sadurní (Begues, Baix Llobregat). El largo fin del Neolítico Antiguo en Cataluña, pp. 867-78 in (P. Arias, R. Ontañon \& C. García-Moncó, eds.) Actas del III Congreso del Neolítico en la Península Ibérica. Monografías del Instituto Internacional de Investigaciones Prehistóricas de Cantabria I: Santander.

Bosch, A., Tarrús, J. Y., Chinchilla, J. J. \& Palomo, A. 2005. Nuevas aportaciones del yacimiento lacustre de La Draga (Banyoles, Girona) al Neolítico Antíguo peninsular. Las campañas del 2000 al 2003, pp. 497-507 in (P. Arias, R. Ontañon \& C. García-Moncó, eds.) Actas del III Congreso del Neolítico en la Península Ibérica. Monografías del Instituto Internacional de Investigaciones Prehistóricas de Cantabria I: Santander.

Bramanti, B., Thomas, M. G., Haak, W., Unterlaender, M., Jores, P., Tambets, K., Antanaitis-Jacobs, I., Haidle, M. N., Jankauskas, R., Kind, C.-J., Lueth, F., Terberger, T., Hiller, J., Matsamura, S., Forster, P. \& Burger, J. 2009. Genetic discontinuity between local hunter-gatherers and central Europe's first farmers. Science 326: 137-40.

Broodbank, C. \& Strasser, T. F. I99I. Migrant farmers and the Neolithic colonization of Crete. Antiquity 65: 233-45.

Cardoso, J. L., Carreira, J. R. \& Ferreira, O. V. 1996. Novos elementos para o estudo do Neolítico antigo da região de Lisboa. Estudos Arqueológicos de Oeiras 6: 9-26.

Chandler, H., Sykes, B. \& Zilhão, J. 2005. Using ancient DNA to examine genetic continuity at the Mesolithic-Neolithic transition in Portugal, pp. $78 \mathrm{I}-86$ in (P. Arias, R. Ontañon \& C. García-Moncó, eds.) Actas del III Congreso del Neolítico en la Península Ibérica. Monografías del Instituto Internacional de Investigaciones Prehistóricas de Cantabria I: Santander.

Costa, L. J. 2004. Nouvelles données sur le Mésolithique des îles tyrrhéniennes (Corse, Sardaigne). Peut-on parler d'un "Mésolithique insulaire"? Gallia Préhistoire 46: 21I-30.

Dennell, R. 1983. European Economic Prehistory. Academic Press: London.

Evans, J. D. I977. Island archaeology in the Mediterranean: problems and opportunities. World Archaeology 9: I2-25.

Fugazzola-Delpino, M. A., d'Eugenio, G. \& Pessina, A. 1993. "La Marmotta” (Anguillara Sabazia, RM). Scavi I989. Un abitato perilacustre di età neolitica. Bullettino di Paletnologia Italiana, nuova serie II, 84: I8I-342.

Fugazzola-Delpino, M. A. \& Mineo, M. 1995. La piroga neolitica del lago di Bracciano ("La Marmotta I"). Bullettino di Paletnologia Italiana, nuova serie II, 86: 197-288.

Gamba, C., Fernández, E., Tirado, M., Deguilloux, M. F., Pemonge, M. H., Utrilla, V., Edo, M., Molist, M., Rasteiro, R., Chikhi, L. \& Arroyo-Pardo, E. 2012. Ancient DNA from an Early Neolithic Iberian population supports a pioneer colonization by first farmers. Molecular Ecology 2I: 45-56.

García, P., Aura, J. E., Bernabeu, J. \& Jordá, J. F. 20Io. Nuevas perspectivas sobre la neolitización en la Cueva de Nerja (MálagaEspaña): la cerámica de la Sala del Vestíbulo. Zephyrus 66: I09-32.
Geddes, D. 1983. Neolithic transhumance in the Mediterranean Pyrenees. World Archaeology I5 (I): 5I-66.

González-Morales, M. I992. Mesolíticos y Megalíticos: la evidencia arqueológica de los cambios en las formas productivas en el paso al megalitismo en la Costa Cantábrica, pp. I85-202 in (A. Moure-Romanillo, ed.) Elefantes, ciervos y ovicaprinos. Economía y aprovechamiento del medio en la Prehistoria de España y Portugal. Universidad de Cantabria: Santander.

Guilaine, J. 2003. De la Vague à la Tombe. La Conquête Néolithique de la Méditerranée. Le Seuil: Paris.

Guilaine, J. \& Manen, C. 2007. From Mesolithic to Neolithic in the Western Mediterranean. Proceedings of the British Academy I44: 2I-5I.

Haak, W., Forster, P., Bramanti, B., Matsumara, S., Brandt, G., Tänzer, M., Villems, R., Renfrew, C., Gronenborn, D., Alt, K. W. \& Burger, J. 2005. Ancient DNA from the first European farmers in 7500-year-old Neolithic sites. Science 310: 1016-18.

Harlan, J. R. 1976. Plant and animal distribution in relation to domestication. Philosophical Transactions of the Royal Society of London B 275: 13-25.

Harrison, R. A. \& Orozco, T. 200I. Beyond characterisation. Polished stone exchange in the Western Mediterranean 5500-2000 BC. Oxford Journal of Archaeology 20 (2): 107-27.

Hedges, R. E., Housley, R. A., Law, L. A. \& Bronk Ramsey, C. 1989. Radiocarbon dates from the Oxford AMS system: datelist 9. Archaeometry 3I (2): 207-34.

1990. Radiocarbon dates from the Oxford AMS system: datelist Io. Archaeometry 32 (I): IOI-8.

Hernández, M. 2006. Arte esquemático en la fachada oriental de la Península Ibérica. 25 años después. Zephyrus 59: I99-2I4.

Hernández, M. \& Martí, B. 2000-I. El arte rupestre de la fachada mediterránea: entre la tradición epipaleolítica y la expansion neolítica. Zephyrus 53-4: 24I-65.

Higgs, E. S. \& Jarman, M. R. 1969. The origins of agriculture: a reconsideration. Antiquity 43: 3I-4I.

Irwin, G. 1992. The Prehistoric Exploration and Colonisation of the Pacific. Cambridge University Press: Cambridge.

Kromer, B. 2009. Radiocarbon and dendrochronology. Dendrochronology 27: 15-I9.

Kunzig, R. 2002. La Marmotta. Discover 23 (II): 34-4I.

Lanfranchi, F. 1998. Prénéolithique ou Mésolithique insulaire? Bulletin de la Société Préhistorique Française 95 (4): 537-45.

Larson, G., Albarella, U., Dobney, K., Rowley-Conwy, P., Schibler, J., Tresset, A., Vigne, J.-D., Edwards, C. J., Schlumbaum, A., Dinu, A., Bâlaçescu, A., Dolman, G., Tagliacozzo, A., Manaseryan, N., Miracle, P., Van Wijngaarden-Bakker, L., Masseti, M., Bradley, D. G. \& Cooper, A. 2007. Ancient DNA, pig domestication, and the spread of the Neolithic into Europe. Proceedings of the National Academy of Sciences USA Io4 (39): $15,276-8 \mathrm{I}$.

Lillios, K. 1997. Amphibolite tools of the Portuguese Copper Age (3000-2000 B.C.): a geoarchaeological approach to prehistoric economics and symbolism. Geoarchaeology I2 (2): 137-63.

2002. Some new views of the engraved slate plaques of Southwest Iberia. Revista Portuguesa de Arqueologia 5 (2): 135-5I.

2008. Heraldry for the Dead: Memory, Identity, and the Engraved Stone Plaques of Neolithic Iberia. University of Texas Press: Austin.

Lubell, D., Jackes, M., Schwarcz, H., Knyf, M. \& Meiklejohn, C. 1994. The Mesolithic-Neolithic transition in Portugal: isotopic and dental evidence of diet. Journal of Archaeological Science 2I: $20 \mathrm{I}-6$. 
Lugliè, C. 2009. L'obsidienne néolithique en Méditerranée occidentale, pp. 213-24 in (M.-H. Moncel \& F. Fröhlich, eds.) L'Homme et le précieux. Matières minérales précieuses. British Archaeological Reports International Series 1934: Oxford.

Malmström, H., Gilbert, M. P. T., Thomas, M. G., Brandström, M., Storå, J., Molnar, P., Andersen, P. K., Bendixen, C., Holmlund, G., Götherström, A. \& Willersellev, E. 2009. Ancient DNA reveals lack of continuity between Neolithic huntergatherers and contemporary Scandinavians. Current Biology I9: $1758-62$.

Malone, C. 2003. The Italian Neolithic: a synthesis of research. Journal of World Prehistory I7 (3): 235-3I2.

Manning, S. W., McCartney, C., Kromer, B. \& Stewart, S. T. 2010. The earlier Neolithic in Cyprus: recognition and dating of a Pre-Pottery Neolithic A occupation. Antiquity 84: 693-706.

Martí, B. \& Hernández, M. S. I988. El Neolític Valencià. Art rupestre i cultura material. Servei d'Investigació Prehistòrica: Valencia.

Olària, C. I988. Cova Fosca. Un asentamiento meso-neolítico de cazadores y pastores en la serranía del Alto Maestrazgo. Servicio de Publicaciones Diputación de Castellón: Castellón.

Özdogan, M. 1997. The beginning of Neolithic economies in southeastern Europe: an Anatolian perspective. Journal of Mediterranean Archaeology 5 (2): I-33.

Peña-Chocarro, L., Zapata, L., Iriarte, M. J., González-Morales, M. \& Straus, L. G. 2005. The oldest agriculture in northern Atlantic Spain: new evidence from El Mirón Cave (Ramales de la Victoria, Cantabria). Journal of Archaeological Science 32: 579-87.

Piqué, R. 2005. Paisaje y explotación de recursos forestales entre el VI y IV milenio cal BC en el nordeste de la Península Ibérica, pp. 45-52 in (P. Arias, R. Ontañon \& C. García-Moncó, eds.) Actas del III Congreso del Neolítico en la Península Ibérica. Monografías del Instituto Internacional de Investigaciones Prehistóricas de Cantabria I: Santander.

Ramis, D., Alcover, J. A., Coll, J. \& Trias, M. 2002. The chronology of the first settlement of the Balearic Islands. Journal of Mediterranean Archaeology I5 (I): 3-24.

Ramos, J., Lazarich, M., Cáceres, I., Pérez, M., Castañeda, V., Herrero, N. \& Domínguez, S. 2003. El asentamiento de El Retamar. Síntesis del registro arqueológico y enmarque socioeconómico e histórico, pp. 509-I8 in (P. Arias, R. Ontañon \& C. García-Moncó, eds.) Actas del III Congreso del Neolítico en la Península Ibérica. Monografías del Instituto Internacional de Investigaciones Prehistóricas de Cantabria I: Santander.

Reimer, P. J., Baillie, M. G. L., Bard, E., Bayliss, A., Beck, J. W., Bertrand, C., Blackwell, P. G., Buck, C. E., Burr, G., Cutler, K. B., Damon, P. E., Edwards, R. L., Fairbanks, R. G., Friedrich, M., Guilderson, T. P., Hughen, K. A., Kromer, B., McCormac, F. G., Manning, S., Bronk Ramsey, C., Reimer, R. W., Remmele, S., Southon, J. R., Stuiver, M., Talamo, S., Taylor, F. W., Van der Plicht, J. \& Weyhenmeyer, C. E. 2009. Intcalog and Marineog radiocarbon age calibration curves, 0-50, ooo years cal вр. Radiocarbon 5I (4): IIII-50.

Robb, J. 200I. Island identities: ritual, travel and the creation of difference in Neolithic Malta. European Journal of Archaeology 4 (2): $175^{-202}$.

Rojo, M. A., Kunst, M., Garrido, R., García, I. \& Morán, G. 2008. Paisajes de la Memoria: asentamientos del Neolítico Antiguo en el Valle de Ambrona (Soria, España), Universidad de Valladolid: Valladolid.

Rottoli, M. \& Castiglioni, E. 2009. Prehistory of plant growing and collecting in northern Italy, based on seed remains from the early Neolithic to the Chalcolithic (c. 5600-2100 cal B.c.). Vegetation History and Archaeobotany I8: 9I-IO3.

Sampietro, M. L., Lao, O., Caramelli, D., Lari, M., Pou, R., Martí, M., Bertranpetit, J. \& Lalueza-Fox, C. 2007. Palaeogenetic evidence supports a dual model of Neolithic spreading into Europe. Proceedings of the Royal Society B 274: 216I-7.

Skeates, R. 2003. Radiocarbon dating and interpretation of the Mesolithic-Neolithic transition in Italy, pp. $157-87$ in (A. J. Ammerman \& P. Biagi, eds.) The Widening Harvest. The Neolithic Transition in Europe: Looking Back, Looking Forward. Archaeological Institute of America: Boston.

Tagliacozzo, A. 2005. Animal exploitation in the Early Neolithic in central-southern Italy. Munibe 57: 429-39.

Tarrús, J. 2008. La Draga (Banyoles, Catalonia), an Early Neolithic lakeside village in Mediterranean Europe. Catalan Historical Review I: 17-33.

Tichý, R. 2001. Expedice Monoxylon. Pocházime z mladší doby kamenné. Univerzity Hradec Králové: Hronov.

Tresset, A. \& Vigne, J.-D. 2007. Substitution of species, techniques and symbols at the Mesolithic-Neolithic transition in western Europe. Proceedings of the British Academy I44: I89-2I0.

Tykot, R. H. 1997. Characterisation of the Monte Arci (Sardinian) obsidian sources. Journal of Archaeological Science 24: 467-79.

2002. Chemical fingerprinting and source tracing of obsidian: the Central Mediterranean trade in black gold. Accounts of Chemical Research 35 (8): 618-27.

Vergès, J.M., Allué, E., Angelucci, D. E., Burjachs, F., Carrancho, Á., Cébrià, A., Expósito, I., Fontanals, M., Moral, S., Rodríguez, A. \& Vaquero, M. 2008. Los niveles neolíticos de la cueva de El Mirador (Sierra de Atapuerca, Burgos): nuevos datos sobre la implantación y el desarrollo de la economía agropecuaria en la submeseta norte, pp. 418-27 in (M. S. Hernández, J. A. Soler \& J. A. López, eds.) Actas del IV Congreso del Neolítico Peninsular. III Congreso del Neolítico en la Península Ibérica. Museo Arqueológico de Alicante y Diputación de Alicante, I: Alicante.

Vigne, J.-D. \& Cucchi, T. 2005. Premières navigations au Proche Orient: les informations indirectes de Chypre. Paléorient 3I (I): $186-94$.

Vigne, J.-D. \& Helmer, D. 1999. Nouvelles analyses sur les débuts de l'élevage dans le Centre et l'Ouest méditerranéens, pp. 129-46 in (J. Vaquer, ed.) Le Néolithique du Nord-Ouest méditerranéen. XXIVe Congrès Préhistorique de France (Carcassonne, 1994). Société Préhistorique Française: Paris.

Villalba, M. J., Bañolas, L., Arenas, J. \& Alonso, M. I986. Les mines neolítiques de Can Tintorer (Gavà). Excavations 1978-1980. Excavations Arqueològiques a Catalunya 6. Departament de Cultura de la Generalitat de Catalunya: Barcelona.

Zapata, L., Baldellou, V. \& Utrilla, P. 2008. Bellotas de cronología neolítica para consumo humano en la cueva de Chaves (Bastarás, Huesca), pp. 402-10 in (M. S. Hernández, J. A. Soler \& J. A. López, eds.) Actas del IV Congreso del Neolítico Peninsular. III Congreso del Neolítico en la Península Ibérica. Museo Arqueológico de Alicante y Diputación de Alicante, I: Alicante.

Zeder, M. A. 2008. Domestication and early agriculture in the Mediterranean Basin: origins, diffusion, and impact. Proceedings of the National Academy of Sciences USA I05 (33): II,597-604.

2009. The Neolithic Macro-(R)evolution: macroevolutionary theory and the study of culture change. Journal of Archaeological Research I7: I-63. 
Zilhão, J. I993. The spread of agro-pastoral economies across Mediterranean Europe: a view from the Farwest. Journal of Mediterranean Archaeology 6 (I): 5-63.

2000. From the Mesolithic to the Neolithic in the Iberian Peninsula, pp. I44-82 in (T. D. Price, ed.) Europe's First Farmers. Cambridge University Press: Cambridge.

200I. Radiocarbon evidence for maritime pioneer colonization at the origins of farming in West Mediterranean Europe. Proceedings of the National Academy of Sciences USA 98: I4I $80-5$.

2003. The Neolithic transition in Portugal and the role of demic diffusion in the spread of agriculture across West Mediterranean Europe, pp. 207-23 in (A. J. Ammerman \& P. Biagi, eds.) The Widening Harvest. The Neolithic Transition in
Europe: Looking Back, Looking Forward. Archaeological Institute of America: Boston.

2009. The Early Neolithic artifact assemblage from the Galeria da Cisterna (Almonda karstic system, Torres Novas, Portugal), pp. 82I-35 in (Collectif) De Méditerranée et d'ailleurs. Mélanges offerts à Jean Guilaine. Archives d'Écologie Préhistorique: Toulouse.

20Ir. Time is on my side ..., pp. 46-65 in (A. Hadjikoumis, E. Robinson \& S. Viner, eds.) The Dynamics of Neolithisation in Europe: Studies in Honour of Andrew Sherratt. Oxbow: Oxford.

Zvelebil, M. 1986. Mesolithic prelude and Neolithic revolution, pp. $5^{-15}$ in (M. Zvelebil, ed.) Hunters in Transition: Mesolithic Societies of Temperate Eurasia and Their Transition to Farming. Cambridge University Press: Cambridge. 